\title{
The New Business Entities in Evolutionary Perspective
}

\section{Citation}

Henry Hansmann, Reinier H. Kraakman \& Richard Squire, The New Business Entities in Evolutionary Perspective, 2005 U. IIL. L. Rev. 5 (2005).

\section{Published Version}

http://illinoislawreview.org/wp-content/ilr-content/articles/2005/1/Hansmann.pdf

\section{Permanent link}

http://nrs.harvard.edu/urn-3:HUL.InstRepos:12070347

\section{Terms of Use}

This article was downloaded from Harvard University's DASH repository, and is made available under the terms and conditions applicable to Other Posted Material, as set forth at http:// nrs.harvard.edu/urn-3:HUL.InstRepos:dash.current.terms-of-use\#LAA

\section{Share Your Story}

The Harvard community has made this article openly available.

Please share how this access benefits you. Submit a story.

Accessibility 


\title{
THE NEW BUSINESS ENTITIES IN EVOLUTIONARY PERSPECTIVE
}

\author{
Henry Hansmann
}

\author{
Reinier Kraakman
}

Richard Squire

February 2005

The authors are grateful to Ofer Eldar and Stacey Delich Gould for extremely able research assistance, and would like to thank Larry Ribstein, Robert Sitkoff, and participants in the University of Illinois conference on “Uncorporations: A New Age?” for valuable comments. 


\title{
THE NEW BUSINESS ENTITIES IN EVOLUTIONARY PERSPECTIVE
}

\author{
Henry Hansmann, Reinier Kraakman, and Richard Squire
}

\begin{abstract}
$\underline{\text { Abstract }}$
The many legal forms for business organizations that first appeared in the U.S. during the last thirty years - the Limited Liability Company (LLC), the Limited Liability Partnership (LLP), the Limited Liability Limited Partnership (LLLP), and the statutory Business Trust - all combine the pattern of creditors' rights, or "asset partitioning," that is traditional to the business corporation with the freedom of contract among investors and managers that is traditional to the partnership. To view these new entities as partnership-like is to treat the degree of freedom of contract as the essential difference between the traditional corporation and partnership forms; to view them as corporationlike is to treat the pattern of creditors' rights as the essential difference. While recent scholarship often takes the former view, the latter seems more accurate. History shows that much of the contractual inflexibility in the traditional corporation served merely to buttress its pattern of creditors' rights, and that this inflexibility fell away upon the development of substitute sources of investor protection. The new forms are thus better understood as part of a continuing development of the corporate form rather than as entities more akin to the traditional partnership, which has in fact been evolving in a different direction.

The essay first develops this argument in terms of the tradeoff between contractual freedom and the form of asset partitioning that to date has received the most scholarly attention - that is, limited liability. It then explores the evolution of the new forms from a less familiar perspective, focusing on the "entity shielding" component of asset partitioning.
\end{abstract}


For the past 200 years business law and scholarship has been dominated by a single business form - the corporation. The age of corporate dominance may, however, be coming to an end. The last decade has seen the rapid development of new types of business associations, including limited liability companies and limited liability partnerships, based on the contractual partnership model rather than the corporate model. We have also seen increased flexibility in existing business forms such as the limited partnership and business trust. These business forms may be ushering in a new age of the "uncorporation."

Brochure, University of Illinois College of Law Conference on “Uncorporation: A New Age?”

The many legal forms for business organizations that first appeared during the last thirty years - the Limited Liability Company (LLC), the Limited Liability Partnership (LLP), the Limited Liability Limited Partnership (LLLP), and the statutory Business Trust - all combine the pattern of creditors' rights (or, as we have characterized it elsewhere, the rules of "asset partitioning") that are traditional to the business corporation with the freedom of contract among investors and managers that is traditional to the partnership. To view these new entities as partnership-like is to treat the degree of freedom of contract as the essential difference between the traditional corporation and partnership forms; to view them as corporation-like is to treat the pattern of creditors' rights as the essential difference. The quotation above suggests the former view. We believe the latter is more accurate. To be sure, both views capture important aspects of the evolution of business entities. But history shows that much of the contractual inflexibility in the traditional corporation served merely to buttress its pattern of creditors' rights, and that this inflexibility fell away upon the development of substitute sources of investor protection. The new forms are thus better understood as part of a continuing development of the corporate form rather than as entities more akin to the traditional partnership, which has in fact been evolving in a different direction.

We develop this argument first in terms of the tradeoff between contractual freedom and the form of asset partitioning that to date has received the most scholarly attention - that is, limited liability. We then explore the evolution of the new forms from a less familiar perspective, focusing on what we term the "entity shielding" component of asset partitioning. ${ }^{2}$

\footnotetext{
${ }^{1}$ Henry Hansmann and Reinier Kraakman, The Essential Role of Organizational Law, 110 YALE L.J. 387 (2000).

${ }^{2}$ We draw here heavily upon our working paper, Henry Hansmann, Reinier Kraakman, and Richard Squire, "Legal Entities, Asset Partitioning, and the Evolution of Organizations" (2004), which explores these themes, and the relevant history, in substantially greater depth and detail.
} 


\section{The Historical Development of Business Entities}

From ancient Roman times until the end of the nineteenth century, the partnership was the dominant form for organizing jointly owned business firms. In fact, until the seventeenth century the partnership was the only form available for most types of business. Partners bore unlimited personal liability for the contractual obligations of the firm, and this was the basis for the firm's creditworthiness.

By the latter half of the nineteenth century, an alternative form of organization, the statutory business corporation, had also become available for most types of business activity. Because the shareholders in a business corporation had limited liability, the obligations of these companies were bonded only by the assets held in the name of the firm itself. This meant that, for the firms to be creditworthy, creditors had to have some reason to believe that the firms would generally maintain reasonable levels of assets, and in particular that the owners of the firms would not opportunistically withdraw assts from the firms or otherwise keep firms undercapitalized.

For the small firms that dominated Western economies prior to the Industrial Revolution, a firm's owners could not credibly make such a pledge to the firm's creditors. The opportunity and incentive to siphon off assets from the firm were too great - a problem that was accentuated by poor accounting standards and weak bankruptcy procedures. Personal liability for the firm's owners was the only way to make the firm creditworthy, and thus the partnership was the dominant mode of organization.

In general, the only means for an equity investor to achieve limited liability in a creditworthy firm were through the limited partnership - a form that has ancient roots and that became available for business of all types, at least on the European Continent, beginning in the fifteenth century. The limited partnership obtained credibility toward creditors by permitting limited liability only for those investors who exercised no control over the firm. The advantage of this rule was that the limited partners, while having an incentive to withdraw assets from the firm opportunistically, lacked power to do so. At the same time, the general partners, who did have the power to dissipate the firm's assets, had little incentive to do so if that would threaten the firm's solvency, as they would be personally liable for any shortfall.

In short, until the rise of the business corporation, an equity investor in a firm could enjoy control with unlimited liability, or limited liability without control, but not both control and limited liability. This last combination evidently was inconsistent with making a firm creditworthy.

\section{Formalism and Creditor Protection}

What permitted the business corporation to succeed in combining limited liability and control? A variety of factors were evidently important, including improved accounting, larger scale for enterprise, better bankruptcy procedures, and more robust securities markets. But the business corporation also dealt with the problem of creditworthiness by adopting a formal structure that constrained shareholder opportunism toward creditors. The early general corporation statutes in the United States were 
principally designed for large firms with numerous shareholders of roughly equal status in terms of earnings and control rights, and with strong delegation of operational authority to an elected board. Control structures that expanded the powers normally attendant upon stock ownership, such as partnership-like arrangements that permitted shareholders to exercise control over management directly, were prohibited. ${ }^{3}$ As a consequence, the withdrawal of assets by owners was conspicuous and easy to monitor. Also, the interest of noncontrolling shareholders were largely aligned with those of creditors, so that efforts by noncontrolling shareholders to protect themselves from exploitation by control persons would also redound to the benefit of the firm's creditors. Legal capital requirements were imposed and given serious effect, as they could be in such large and formal structures.

Such rigid structures were not, however, well suited to small or closely-held firms, which required customized allocations of earnings and control. Consequently, small firms generally continued to be organized in the partnership form, in which these attributes were not just easy to establish but were in fact the default rules.

Beginning in the late nineteenth century, the restrictions on the corporate form began to be relaxed, making the form increasingly suitable for - and thus increasingly used by - small-scale enterprises of the type that previously would have become partnerships. At the same time, legal capital requirements became increasingly flexible. In part this liberalization occurred through the revision of the general business statutes and their judicial interpretation, and in part through the adoption of special close corporation statutes. ${ }^{4}$

What accounts for this liberalization? An important factor, we suggest, was increasing sophistication in financial contracting that permitted firm creditors to evaluate, monitor, and control more precisely the creditworthiness of the firms in which they invested. Improved accounting and disclosure, the adoption of federal bankruptcy law in 1898 and its subsequent evolution, the imposition of federal corporate income taxation in 1909 (which demanded clear and accurate accounting), the growth of credit rating agencies, greater financial literacy among businesspersons, and better communications presumably all contributed to this development. It became possible to give both control and limited liability to the owners of small firms without rendering the firms uncreditworthy.

The new entity forms of the past 30 years represent a continuation of this process. Although such entities provide limited liability, they also permit the freedom of internal structure that was long available only in the general partnership. How much of an incremental change they constitute is, to be sure, debatable; by the time they arose, there was already great flexibility available in the close corporation. In fact, the new forms were at first motivated largely by tax considerations rather than by a desire for increased flexibility in business entities. Nevertheless, the new forms now offer at least some

\footnotetext{
${ }^{3}$ See Jesse H. Chopper, John C. Coffee, and Ronald J. Gilson, CASES AND MATERIALS ON CORPORATIONS ( $5^{\text {th }}$ ed., 2000), at 18-22, 712; Lawrence M. Friedman, A HISTORY OF AMERICAN LAW (2d ed., 1985) at 511-525; George D. Hornstein, Judicial Tolerance of the Incorporated Partnership, 18 LAW \& CONTEMP. PROBS 435, 439-48 (1953).

${ }^{4}$ See id.
} 
degree of flexibility that was previously unavailable in limited liability entities. Indeed, Delaware's business trust statute of $1988^{5}$ arguably represents the logical culmination of this evolution: by eliminating all remaining ambiguity as to the availability of whether limited liability for the beneficiaries of private trusts, ${ }^{6}$ it established a limited-liability form that provides nearly complete freedom of contract as to control, allocation of earnings, and even fiduciary duties.

These developments have rendered the control rule of the limited partnership anachronistic, and with the availability of the LLP and the LLLP, that rule has effectively been abandoned. ${ }^{7}$

\section{The Continuing Role of the Partnership}

These developments do not mean, however, that the partnership has been rendered obsolete. To the contrary, the partnership remains useful for situations where the firm's own assets might not constitute a credible bond and thus the firm's owners, whether they are individuals or other firms, must pledge all of their respective assets in support of the firm's obligations to make the firm creditworthy. In fact, the partnership's suitability to this role was recently enhanced. In 1715, the Anglo-American partnership was given a modest degree of limited liability. An English court of equity ruled that year that, if a partner and his partnership were both bankrupt, the partner's personal creditors enjoyed a claim prior to that of the partnership creditors to the partner's personal assets. ${ }^{8}$ That is, partnership creditors could levy upon a partner's personal assets only if the personal creditors had already been paid in full. This rule remained in effect in the U.S. until 1978, when it was abandoned in favor of the rule that had prevailed for thousands of years before 1715: partnership creditors share equally with a partner's personal creditors in the partner's personal assets. ${ }^{9}$

Why the reversion? The evident rationale is that the 1715 priority rule worked a compromise. Partnerships of the time were not creditworthy without personal liability. At the same time, considerations suggested that firm creditors could monitor firm assets more cheaply than could personal creditors, who enjoyed a corresponding advantage with respect to personal assets. So partnership creditors were given (in 1682) priority in partnership assets, ${ }^{10}$ but were then (in 1715) subordinated in their claim to personal

\footnotetext{
${ }^{5}$ DeL. CoDE AnN. tit. 12, §§ 3801-3862 (2001). For a thoughtful study of the development and character of the statutory business trust, see Robert Sitkoff, Trust As Uncorporation: A Research Agenda, 2005 U. ILL. L. REV.

${ }^{6}$ Henry Hansmann and Ugo Mattei, The Functions of Trust Law: A Comparative Legal and Economic Analysis, 73 NEW YoRK UNIVERSITY LAW REVIEW 434, 474-75 (1998).

${ }^{7}$ This is not to say that most limited partnership statutes do not retain this rule. But practically speaking, if one wants to have limited liability and also exercise all the control powers typical of a partner, one can simply form one's business as an LLP, LLLP, or statutory business trust.

${ }^{8}$ Ex parte Crowder, Equity Cases Abridged 56, 21 ER 870.

${ }^{9}$ The rule change was a result of the Bankruptcy Act of 1978. See 11 U.S.C. § 723. It has also become a substantive rule of partnership law in those states adopting the Revised Uniform Partnership Act. See generally William Allen and Reinier Kraakman, COMMENTARIES AND CASES ON THE LAW OF BusinesS ORGANIZATION 56-8 (2003). The 1715 rule remains in effect in England.

${ }^{10}$ Craven v. Knight, 2 Chancery Reports 226, 21 ER 664.
} 
assets. When, however, the corporate form with its full limited liability became a feasible means of organizing small firms, there was no longer a need for the compromise of 1715. The partnership form could be tailored to those who wanted to pledge their personal assets in full to their business ventures, and the corporate form could be employed by firms whose business creditors were willing to rely just solely on business assets. Positions between these extremes could be achieved by mixing or modifying the forms, or by customized contracting between the firm and its creditors.

In short, the partnership continues to play its historical role as the business form that allows owners to pledge their personal assets to bond the firm's contracts, while corporate-type entities - including each of the new forms of the past thirty years serve to bond the firm's contracts only with the firm's own assets. The important change over time - and it has been gradual rather than sudden - is the emergence of various economic, technological, and legal factors that broaden the set of firms whose debts can be bonded with their own assets (that is, that have limited liability).

This view of organizational evolution suggests a reason why European jurisdictions were far ahead of U.S. jurisdictions in adopting highly flexible limited liability forms for small businesses. The German LLC form (the GmbH) dates from the 1890s, while the French LLC form (the SARL) appeared in the 1920s. ${ }^{11}$ Both are highly contractual limited liability vehicles for closely-held businesses. Perhaps Germany and France offered these flexible forms so long ahead of U.S. jurisdictions because of the procreditor orientation of European law as contrasted with the pro-debtor orientation of U.S. law. The traditionally strong European creditor-protection measures -- such as mandatory disclosure of financial statements by closely-held companies, minimum capital requirements, and creditor-oriented bankruptcy rules ${ }^{12}$-- may have been the precondition for increased contractual freedom among investors.

\section{Entity Shielding}

We have spoken so far as if limited liability were the principal feature that distinguishes the corporation from the partnership.

An even more important distinction, however, lies in what we have elsewhere termed "affirmative asset partitioning ${ }^{13}$," and what we here will simply call "entity shielding ${ }^{14}$." In a sense, entity shielding is the reverse of limited liability: while limited liability shields the assets of a firm's owners from the claims of the firm's creditors, entity shielding protects the assets of the firm from the claims of the owners' personal creditors. Entity shielding and limited liability are forms of asset partitioning, in that they allocate claims to the assets of a firm and claims to the personal assets of the firm's owners to different groups of creditors.

\footnotetext{
${ }^{11}$ See Jacques Treillard, The Close Corporation in French and Continental Law, 17 LAW \& CONTEMP. PROBS. 546 (1953)

${ }^{12}$ Reinier Kraakman et al., The ANATOMY Of CoRporate LAW 97-99 (2004).

${ }^{13}$ Hansmann and Kraakman, supra note 1, at 393.

${ }^{14}$ This terminology, and the concepts of weak and strong entity shielding described immediately below, are taken from Hansmann, Kraakman, and Squire, supra note 2.
} 
Entity shielding, for our purposes here, comes in two forms. "Weak" entity shielding is what one finds in the traditional partnership: firm creditors enjoy first claim, over the owners' personal creditors, to firm assets. This has the virtue of reducing monitoring costs for firm creditors by giving them, in effect, a security interest in firm assets. "Strong" entity shielding, in turn, is what one finds in the business corporation. It adds to weak entity shielding a rule of liquidation protection, under which neither an owner nor his personal creditors may demand unilaterally a payout of the owner's share of firm assets. In effect, with strong entity shielding an owner and his personal creditors lose the withdrawal right that characterizes the traditional partnership at will. Strong entity shielding has the advantage of protecting a firm's going-concern value (or, as economists would put it, the value of firm-specific investments).

The corporation, then, is characterized by both strong entity shielding and limited liability, while the traditional partnership lacks limited liability and has been characterized by only weak entity shielding or (prior to the seventeenth century) none at all. This pattern of differentiation is not accidental. Strong entity shielding and limited liability are highly complementary; the presence of one generally calls for the other. The loss of the withdrawal right that constitutes strong entity shielding would render an owner's investment in the firm illiquid, if the investment were not transferable. Transferability of shares, intern, calls for limited liability. ${ }^{15}$ Moreover, the loss of withdrawal rights removes an important source of protection for owners of minority shares against exploitation by control persons. Limited liability has the advantage of capping the losses that minority shareholders can suffer from such exploitation.

Conversely, limited liability generally requires strong entity shielding, largely because limited liability increases the incentive for owners to withdraw from the firm when its prospects are doubtful. That incentive, in turn, creates the threat of a run on the firm's assets, which would destroy going-concern value to the detriment of both the firm's creditors and its owners. ${ }^{16}$ By denying owners the power to withdraw unilaterally, strong entity shielding prevents such runs.

We have argued above that limited liability requires accounting innovations and monitoring technology that permit creditors to rely on a firm's assets. But accounting and monitoring methods for small firms until recently were highly imperfect, with the consequence that limited liability tended to be confined to large firms with a standardized and easy-to-monitor ownership structure. Improvements in the technology of financial monitoring have permitted extension of limited liability to smaller and more closely controlled firms.

A similar argument can be offered for strong entity shielding. As we have noted, the loss of withdrawal rights that characterizes strong entity shielding removes an important source of protection for owners of minority shares in a firm. When general incorporation statutes were first enacted in the nineteenth century, the rigid structure that

\footnotetext{
${ }^{15}$ See Easterbrook \& Fischel, Limited Liability and the Corporation, 52 U. Chi. L. Rev. 89, 92 (1985). In fact, unlimited liability is compatible with tradable shares so long as the liability is pro rata rather than joint and several. See Hansmann, Henry \& Reinier Kraakman, Toward Unlimited Shareholder Liability for Corporate Torts, 100 YALE L.J. 1879, 1903-04 (1991).

${ }^{16}$ Another important reason why limited liability requires strong entity shielding is that it otherwise would expose firm creditors to excessive opportunism by a firm's owners.
} 
these statutes imposed compensated for the loss of the withdrawal right by constraining control-person opportunism toward shareholders as well as toward creditors. Important in this respect were rules designed to prevent the decoupling of control and income rights from shareholdings, such as prohibitions on shareholder voting agreements, rigid prohibitions on self-dealing transactions, and narrow interpretations of corporate purposes. Early corporation law also forbade restrictions on the free alienability of shares, thereby ensuring that shareholders who lacked withdrawal rights might have an alternate source of liquidity.

While such rigidity mitigated governance and liquidity problems associated with strong asset partitioning, it was, as we observed above, often incompatible with the needs of small, closely-held firms, in which flexibility in allocating control and income rights, and restrictions on alienation of shares, can be essential. The relaxation of this rigidity in corporate law over the intervening century suggests that sources of protection for noncontrolling owners have arisen that are superior both to the withdrawal right and to formal restrictions on the allocation of earnings and control.

In part these new sources of protection are the same as those that redounded to the benefit of firm creditors - developments that have made it easier for outsiders to monitor a firm's financial status and performance. Another source of protection, which appears particularly important for the viability of strong entity shielding, is increased sophistication on the part of courts in evaluating the behavior of corporate insiders. This has permitted courts to employ refined fiduciary duties in place of outright bans on particular ownership structures or transaction types. Increased sophistication in valuation techniques also reduces the need to rely upon liquidation of a firm to determine the value of an owner's share if he or his creditors need to be bought out.

The new forms of the past thirty years are the culmination of this process of extending strong entity shielding to less restricted entity types. Strong entity shielding in perpetuity is available in the LLC. ${ }^{17}$ And recent statutory changes make clear that owners may opt for strong entity shielding for a defined period in even the partnership by forming a partnership for a term or specific undertaking. ${ }^{18}$ Such strong entity shielding in the partnership can be combined with limited liability through the LLP or LLLP. Finally, strong entity shielding is the default rule in the statutory business trust, with its unrestricted liberty of structure. $^{19}$

\footnotetext{
${ }^{17}$ In the Limited Liability Company Act of 1996, the default regime for member withdrawal is the same as under the Revised Uniform Partnership Act: A member may withdraw, rightfully or wrongfully, at any time; if the company is at will he must be bought out immediately, but if the company is for a term then buyout need not occur until the term's expiration. L.L.C.A. §§ 602(a), 701(a). The LLC Act expressly provides, however, that most of its rules may be altered in the company's operating agreement, including those respecting a member's withdrawal voluntarily or due to his bankruptcy. Id. §§ 103, 601(1), (7). Moreover, the Act explicitly provides that the rules for determining whether a member's withdrawal is wrongful apply only if "the operating agreement has not eliminated a member's power to dissociate." Id. § 602(b). Members of an LLC thus may contract for strong-form entity shielding and full liquidation protection in perpetuity with respect to themselves and their personal creditors. The only exception is that companies must retain procedures for dissolution or the expulsion of members upon a judicial finding of persistent misconduct or that the purpose of the company has been frustrated. Id. § 103 (5),(6).

${ }^{18}$ See UNIF. P’SHIP ACT $\S \S 701(\mathrm{~h}), 801(2)$ (1997), 6 U.L.A. (pt. 1) 189 (2001).

${ }^{19}$ See Del. Code AnN. Tit. 12, § 3808(a)-(b) (1999 \& Supp. 2004).
} 
Meanwhile, the traditional partnership still plays a role with respect to entity shielding as it does with respect to limited liability. With only weak rather than strong entity shielding, the traditional partnership-at-will continues to provide a convenient entity form for owners who wish to retain a right of unilateral withdrawal as a governing device or source of liquidity.

\section{How Many New Forms?}

In short, the new statutory forms for commercial enterprise - the LLC, the LLP, the LLLP, and the business trust - are best seen as generalizations of the business corporation. They combine the pattern of asset partitioning provided by the traditional corporation — strong entity shielding and full limited liability - with the greater flexibility in internal structure that the corporate form has evolved to offer. Meanwhile, the general partnership continues to provide a very different pattern of asset partitioning weak entity shielding and unlimited personal liability - for those firms that require it.

How many different corporate-type forms are required for the sake of efficiency, and how these forms are best structured, are questions that remain subject to debate and experimentation. In theory, any entity that can be formed as a business corporation, an LLC, an LLP, or an LLLP could be fashioned instead as a statutory business trust simply by specifying the necessary structure in the trust's governing instrument. If the more restricted forms continue to serve a purpose, it is perhaps that they permit types of signaling and bonding that the business trust cannot provide. Alternatively, the various alternative forms may have the virtue of offering specialized sets of default rules that are suitable to different types of firm and that, if put instead in a firm's governing instrument, might prove either too flexible or too rigid. ${ }^{20}$ Unfortunately, we do not understand these functions of legal forms well enough to reach consensus on their appropriate number and structure. $^{21}$ Not surprisingly, then, the new entity forms have been protean, and we can expect further sorting among them.

\footnotetext{
${ }^{20}$ See Henry Hansmann, “Corporation and Contract” (2004).

${ }^{21}$ This is not to say that the new forms have not been the subject of thoughtful analysis. Their emergence has elicited insightful commentary by, in particular, Larry Ribstein, whose extensive writings on these forms provide our most substantial source of wisdom concerning them. See, e.g., Larry Ribstein, Why Corporations?, Illinois Public Law and Legal Theory Research Papers Series Research Paper No. 03-11 (2004).
} 